$\% \mathrm{Na}_{2} \mathrm{CO}_{3}$, filtrierte sie durch ein Tuch und durch Filtrierpapier-Brei. Aus dem klaren Filtrat scheidet sich nach Zusatz von verd. $\mathrm{HCl}$ die Alginsäure aus, der Niederschlag wird nochmals durch ein Tuch filtriert.

Obige Ausführung wird $3 \mathrm{mal}$ wiederholt und zuletzt mit Alkohol und Aether gewaschen.

Die Wasserauszüge aus den Eingeweiden (hauptsächlich aus der sogenannten "Leber") des Seeohrs (Haliotus giganteus Gm.) und des Seeigels (Sphaerechinus pulcherrimus Ag.) konnten stark die Alginsäure spalten. Der Autor prüfte es durch die Viscositätsänderung der Alginsäurelösung und durch die Reduktionsfähigkeitszunahme der Fehlingschen I,ösung, und die optimale Wasserstoffionkonzentration von der Wirksamkeit der Viscositätsänderung war pH 7.2. Der Autor hat dieses Enzym als Alginase bezeichnet.

Aber durch die Auszüge aus Schweine Pankreas, Krabben Leber, Haifisch Darm, einem Schimmelpilz (Asp. oryzae Cohn) und Seesternen konnte die Säure gar nicht gespalten werden. Man kann vermuten, dass es Alginsäure spaltendes Enzym nur in den Tieren gibt, die auf alginsäurehaltigen Pflanzen, d. h. braunen Algen, fressen und leben.

\title{
Studies on the Vitamin D
}

III. Antirachitic Activation of Ergosterol by means of the Action of Ozone and on the Chemical

Nature of Vitamin D.

By

\section{Etsuo Takamiya}

(Received November 26th, 1930)

In the present investigation I attempted a feeding experiment to ascertain whether ergosterol becomes an antirachitically active substance after the action of ozone or not, in the same way as ergosterol becomes active after irradiation with ultra-violet rays. And the chemical nature of vitamin $\mathrm{D}$ was dis cussed with the experimental results obtained.

Ergosterol was isolated from beer-yeast by means of the Heidushka and Lindner's modification of which melting point was $154^{\circ} \mathrm{C}$ (uncorrected). The ergosterol in itself was antirachitically inactive on a feeding experiment. Shimazu's primitive ozone-generator with one-tube was especially employed in this experiment for the reason stated in the original paper. Ergosterol (20 
mg.) was dissolved in 10 c.c. of olive oil and then ozonized for a definite time.

From the results of the feeding experiments it became experimentally certain that ergosterol becomes an antirachitically active substance after the action of ozone. And it became evident also that the rate of activation of ergosterol increased after the action of ozone and then reached a maximum potency and from this time further action caused a falling off in potency, the product becoming completely inactive (one can readily see the presence of such a phenomenon also in the case of the activation of ergosterol through the irradiation with ultra-violet rays). And it was suggested from my experimental results that $J_{1}$ mono-ozonide ergosterol will possibly be vitamin D. And also it was roughly concluded such that the imperfectly ozonized ergosterol is vitamin $\mathrm{D}$.

\section{Studies on the Specific Properties of Protease and Amylase from the Standpoint of the Adsorption Phenomena.}

III. The Relative Observation between the Enzymic Power of purified Enzyme Solution prepared by the Enzyme

Adsorption of Aluminium Hydroxide and the Nitrogen Content of the same Solution.

By

Fumiwo Hemmi and Goro Inami.

(From the Research Laboratory of the Agricultural Technology, College of Agriculture, Hokkaido Imperial University)

(Received December 25th, 1930)

In our first paper, we had already reported on some specific properties between protease and amylase of Taka-diastase and pancreatin from the standpoint of the adsorption phenomena by using aluminium hydroxide and kaolin. Afterwards, in the second paper, we also described the results of the fractional separation of these two kinds of enzyme by the application of a selective adsorption of enzyme.

As we believe that it is one of the most important problems in the enzyme chemistry to separate the enzyme substance in a pure form as possible, we have further continued our experiment in which we had repeated the 